\title{
Soil management and mulching for weed control in cowpea ${ }^{1}$
}

\author{
Sebastião de Oliveira Maia Júnior ${ }^{2}$, Jailma Ribeiro de Andrade², \\ Lígia Sampaio Reis ${ }^{2}$, Luciene Ribeiro de Andrade $^{2}$, Ana Cláudia de Melo Gonçalves ${ }^{3}$
}

ABSTRACT

More efficient weed control managements can be achieved through different strategies, given that the population of these plants changes according to the system used. This study aimed at assessing solarization methods associated with different mulches for weed control in the cowpea crop. The methods used were soil solarization, with plastic sheeting and with solar collector, associated with the following mulches: castor bean, rattlepod and spontaneous vegetation. Weed phytosociology was calculated by frequency, density and abundance. The most infesting families were Asteraceae, Poaceae and Amaranthaceae. The species with the highest frequency, density and abundance in the treatments without mulching was Cyperus rotundus, while Bidens spp. occurred only in non-solarized soil and without mulching. The largest number of weeds was found in the treatments without mulching in non-solarized soil or soil solarized with plastic sheeting, the latter being less efficient than the solar collector. Mulching inhibits the weed infestation in cowpea crops, irrespective of soil solarization. However, rattlepod as mulch is more efficient in the solarization with plastic sheeting than with a solar collector.

KEYWORDS: Vigna unguiculata L.; weed species; solarization.

\section{INTRODUCTION}

The yield of different crops, such as cowpea [Vigna unguiculata (L.) WALP], may be affected by a series of biotic and abiotic stresses that change their growth and development, including weed infestation (Freitas et al. 2009, Silva et al. 2012). Weeds compete interspecifically with crops for available resources such as nutrients, water, light and space, thereby

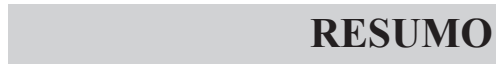

Manejo de solo e plantas de cobertura no controle de plantas daninhas em feijão-caupi

Manejos mais eficientes de plantas daninhas podem ser alcançados com diferentes estratégias, visto que a população dessas plantas é modificada de acordo com o sistema utilizado. Objetivouse avaliar métodos de solarização associados a diferentes coberturas vegetais para o controle de plantas daninhas na cultura do feijão-caupi. Os métodos utilizados foram solarização do solo, com plástico e com coletor solar, associados às coberturas vegetais mamona, crotalária e vegetação espontânea. A fitossociologia das plantas daninhas foi calculada pela frequência, densidade e abundância. As famílias mais infestantes foram Asteraceae, Poaceae e Amaranthaceae. A espécie de maior frequência, densidade e abundância nos tratamentos sem cobertura de solo foi Cyperus rotundus, enquanto Bidens spp. ocorreu apenas em solo não solarizado e sem cobertura. $\mathrm{O}$ maior número de plantas daninhas foi encontrado nos tratamentos sem cobertura morta em solo sem solarização ou solarizado com plástico, o qual foi menos eficiente que o coletor solar. A cobertura morta inibe a infestação de plantas daninhas na cultura de feijão-caupi, independentemente da solarização do solo. Contudo, a cobertura com crotalária é mais eficiente na solarização com o plástico que com o coletor solar.

PALAVRAS-CHAVE: Vigna unguiculata L.; espécies infestantes; solarização.

affecting yield (Monquero et al. 2009, Cardoso et al. 2013, Tavares et al. 2013).

Weeds may also act on crops by releasing allelochemical substances, mediators which promote inhibitory effects that compromise crop growth (Scholberg et al. 2006, Gatti et al. 2010). A number of techniques may be efficient for controlling the weed infestation in commercial crops, such as soil solarization and mulching (Baptista et al. 2006,

1. Received: Jun. 19, 2018. Accepted: Nov. 12, 2018. Published: Dec. 13, 2018. DOI: 10.1590/1983-40632018v4853564.

2. Universidade Federal de Alagoas, Centro de Ciências Agrárias, Rio Largo, AL, Brasil.

E-mail/ORCID: juniormaiagrari@hotmail.com/0000-0002-3018-9030,jailma_asf@hotmail.com/0000-0003-1790-8544, lavanere@ufal.edu.br/0000-0001-8101-396X, luciene.bio.cca@gmail.com/0000-0002-6920-5499.

3. Universidade Federal da Paraíba, Centro de Ciências Agrárias, Areia, PB, Brasil. E-mail/ORCID: acdemelogoncalves@gmail.com/0000-0002-8631-0127. 
Candido et al. 2011, Soares et al. 2011, Samtani et al. 2017), which significantly reduce weed emergence and development (Ricci et al. 2000, Vincensi et al. 2011). Thus, the association of these control methods may be an effective alternative to minimize losses caused by weed infestation in cowpea crops.

Soil solarization, a technique in which wet soil is covered by plastic sheeting or similar products and heated by sunlight for several days, creates conditions that are harmful to a number of weeds (Ricci et al. 2000, Samtani et al. 2017). Moreover, the effect of solarization on increasing plant growth and crop yield has also been reported, not only due to weed control, but also heat-induced nutrient release into the soil (Stapleton \& DeVay 1995). Mulching decreases the weed population by hindering emergence, primarily in the initial crop phase, in addition to increasing the organic matter in the soil and preventing erosion caused by rainfall (Monquero et al. 2009, Pereira et al. 2011). This is because the weed population changes in the presence of mulch, in which suppression is attributed to physical, chemical and biological factors (Soares et al. 2011, Flôres et al. 2017).

The knowledge on weed populations in crops is achieved primarily based on a phytosociological survey, indicated as an important factor in the decision-making process of weed control methods (Soares et al. 2011, Lima et al. 2016). Furthermore, studies also investigated the intensity of weed interference in crops, which is determined by the floristic composition of the cultivated area, producing specific frequency, density and abundance data, also important in assessing the impacts of weeds on farm management systems (Kuva et al. 2003, Cabral et al. 2013). These assessments are useful in establishing the weed population to determine the most important species to control (Cabral et al. 2013, Rodrigues et al. 2017). As such, this study aimed to assess the effects of soil solarization and mulching to control weeds in the cowpea crop.

\section{MATERIAL AND METHODS}

The experiment was conducted in a moisturefree environment at the Universidade Federal de Alagoas, in Rio Largo, Alagoas state, Brazil ( $09^{\circ} 28^{\prime} \mathrm{S}, 35^{\circ} 49^{\prime} \mathrm{W}$ and $127 \mathrm{~m}$ of altitude), whose climate is characterized as hot and wet.

The study consisted of two stages: the first between October and December 2016 and the second between January and April 2017, corresponding to two types of solarization. The experimental design was entirely randomized, with eight treatments and four repetitions, totaling 32 plots, each represented by one plant per pot. The treatments were: T1 (solarized soil + castor bean as mulch); T2 (solarized soil with rattlepod as mulch); T3 (solarized soil with spontaneous vegetation as mulch); T4 (solarized soil with no mulch); T5 (non-solarized soil + castor bean as mulch); T6 (non-solarized soil + rattlepod as mulch); T7 (non-solarized soil + spontaneous vegetation as mulch); and T8 (control - non-solarized and no mulch).

Pots containing $8 \mathrm{~kg}$ of a cohesive sandy clay loam Yellow Latosol, previously ground, sieved and solarized by two different methods (plastic sheeting and solar collector), were used.

Solarization with plastic was performed with soil irrigated close to the field capacity, totally covering a $10-\mathrm{cm}$ layer in $50-\mu \mathrm{m}$ black plastic sheeting and exposing it to the sun for 30 days. Thus, in addition to heating the soil at a temperature of up to $45^{\circ} \mathrm{C}$, plastic does not allow the sunlight to reach the soil, inhibiting the weed propagule development.

Solarization with a solar collector was also carried out with the soil irrigated close to the field capacity and deposited in a series of black steel pipes, arranged horizontally on a wooden support, exposing them to the sun for 15 days. This process consists of heating the soil to a temperature of $60-67^{\circ} \mathrm{C}$.

Three types of mulch were tested on the soil simultaneously to solarization: castor bean (Ricinus communis), rattlepod (Crotalaria ochroleuca) and spontaneous vegetation that was obtained in noncultivated areas.

Three cowpea seeds were planted in each pot. Thinning was performed at 7 days after planting (DAP), leaving only one plant per pot added to the mulch $\left(100 \mathrm{~g} \mathrm{pot}^{-1}\right)$, keeping the soil irrigated close to the field capacity.

The weeds were assessed in each experimental unit at 80 DAP, using a phytosociological survey. Sampling consisted of collecting plants by randomly throwing a $25 \mathrm{~cm}^{2}$ quadrat into the plot (BraunBlanquet 1979).

All the weed species in the pots were identified, determining the number and total dry weight, in addition to the phytosociological indices frequency, density and abundance, where frequency is the number of plots containing the species/number of plots, density the number of individuals per species/ 
total area collected and abundance the number of individuals per species/number of plots containing the species.

After the collected material was identified, it was placed in an air circulating oven at $65{ }^{\circ} \mathrm{C}$, for $48 \mathrm{~h}$, in order to obtain the dry weight. Next, the material was weighed on a precision scale $(0.01 \mathrm{~g})$.

The data were submitted to analysis of variance using the F-test $(\mathrm{p}<0.05)$ and the means were compared by applying the Scott-Knott test, using the Sisvar 5.6 software.

\section{RESULTS AND DISCUSSION}

The phytosociological survey conducted in two stages of the experiment revealed 14 weed species belonging to 7 families, as it follows: Amaranthaceae, Asteraceae, Cyperaceae, Euphorbiaceae, Lamiaceae, Malvaceae and Poaceae (Table 1).

The families with the highest population densities were Cyperaceae with 113 individuals, Poaceae with 86 and Amaranthaceae with 82. Those with the greatest species diversity were Asteraceae with 4 species, followed by Poaceae with 3, and the species with the highest density were Cyperus rotundus, Brachiaria decumbens and Amaranthus deflexus.

Similar results were found by Salgado et al. (2007), who assessed the interference of weeds in common bean crop. They observed 13 species, most of which belonging to the families Asteraceae and

Table 1. Family, scientific and common name of weeds identified in the soils with and without solarization associated with mulches in the cowpea crop.

\begin{tabular}{|c|c|c|}
\hline \multirow{2}{*}{ Family } & \multicolumn{2}{|c|}{ Species } \\
\hline & Scientific name & Common name \\
\hline \multirow[t]{3}{*}{ Amaranthaceae } & Alternanthera tenella & Parrotleaf \\
\hline & Amaranthus deflexus & Large fruit amaranth \\
\hline & Amaranthus spinosus & Spiny amaranth \\
\hline \multirow[t]{4}{*}{ Asteraceae } & Bidens spp. & Black jack \\
\hline & Conyza spp. & Horseweed \\
\hline & Galinsoga parviflora & Gallant soldier \\
\hline & Tridax procumbens & Coatbuttons \\
\hline Cyperaceae & Cyperus rotundus & Common nut sedge \\
\hline Euphorbiaceae & Chamaesyce hirta & Pillpod sandmat \\
\hline Lamiaceae & Leonotis nepetifolia & Lion's ear \\
\hline Malvaceae & Sida rhombifolia & Jelly leaf \\
\hline \multirow[t]{3}{*}{ Poaceae } & Brachiaria decumbens & Signal grass \\
\hline & Brachiaria brizantha & Palisade grass \\
\hline & Digitaria horizontalis & Jamaican crabgrass \\
\hline
\end{tabular}

Poaceae. Likewise, these families exhibited a greater weed species density in common bean plants (Tavares et al. 2013). According to these authors, Asteraceae and Poaceae were the main weed families found in crops grown in Brazil. This is because most the species from these families produce an abundance of diaspores, what facilitates their dissemination and occupation of an ecological niche in a number of environments, even under adverse conditions (Cardoso et al. 2013, Rodrigues et al. 2017), making techniques such as solarization and mulching, aimed at inhibiting the infestation of these species, very important.

The largest number (25.2 and 23.2) and highest dry weight content $\left(12.8 \mathrm{~g} \mathrm{~m}^{-2}\right.$ and $\left.22.2 \mathrm{~g} \mathrm{~m}^{-2}\right)$ of weeds collected in the first stage of the experiment were found in treatments without mulching (T4 and $\mathrm{T} 8$, respectively), irrespective of solarization (Table 2). This is due to the physical effect of mulching, which inhibits weed germination, and even if this occurs, their reserves are not sufficient to guarantee the survival in the space occupied inside the mulch until they gain access to light and photosynthesis initiates (Monquero et al. 2009).

Of the identified species, $C$. rotundus L. had the highest number of individuals in the treatments without mulching (T4 and $\mathrm{T} 8$ ), regardless of solarization. However, this species exhibited a lower dry weight, when compared to other species with a smaller number of individuals, such as A. deflexus, Conyza spp. and Sida rhombifolia. Bidens spp. occurred only in non-solarized soil with no mulching (T8), while $S$. rhombifolia was observed in solarized soil without mulching and non-solarized soil with mulching (T4, T5, T7 and T8).

The $C$. rotundus species was also reported as the most common weed in sugarcane (Soares et al. 2011) and vegetable crops (Ricci et al. 2000). In vegetable crops, the weed was inhibited by soil solarization, what was not observed in the present study, where only mulching inhibited the infestation. This likely occurred due to the use of plastic sheeting in the vegetable crop, since, when it was removed, the reinfestation reached $41 \%$, while, in this study, the crop was only planted after the soil was solarized.

Mulching was efficient in controlling weeds in the cowpea crop, as reported in other studies (Monquero et al. 2009, Flôres et al. 2017). Meschede et al. (2007) concluded that different types of plant cover on the soil, such as sorghum, millet and 
Table 2. Number $\left(\mathrm{n} ; \mathrm{n} \mathrm{m}^{-2}\right)$ and dry weight $\left(\mathrm{dw} ; \mathrm{g} \mathrm{m}^{-2}\right)$ of weeds in soil with and without solarization with plastic sheeting associated with mulches in a cowpea crop.

\begin{tabular}{|c|c|c|c|c|c|c|c|c|c|c|}
\hline \multirow{2}{*}{ Weeds } & \multirow{2}{*}{ Parameters } & \multicolumn{8}{|c|}{ Treatments } & \multirow{2}{*}{ F-value } \\
\hline & & T1 & $\mathrm{T} 2$ & $\mathrm{~T} 3$ & $\mathrm{~T} 4$ & T5 & T6 & $\mathrm{T} 7$ & T8 & \\
\hline \multirow[t]{2}{*}{ Amaranthus deflexus } & $\mathrm{n}$ & $0.25 \mathrm{~b}$ & $1.25 \mathrm{~b}$ & $0.50 \mathrm{~b}$ & $3.75 \mathrm{a}$ & $1.75 \mathrm{~b}$ & $0.75 \mathrm{~b}$ & $1.25 \mathrm{~b}$ & $3.50 \mathrm{a}$ & $3.77 * *$ \\
\hline & $\mathrm{dw}$ & $0.26 \mathrm{~b}$ & $1.78 \mathrm{~b}$ & $0.07 \mathrm{~b}$ & $2.87 \mathrm{a}$ & $1.91 \mathrm{~b}$ & $0.28 \mathrm{~b}$ & $1.07 \mathrm{~b}$ & $4.36 \mathrm{a}$ & $5.29 * *$ \\
\hline \multirow[t]{2}{*}{ Bidens spp. } & $\mathrm{n}$ & $0.00 \mathrm{~b}$ & $0.00 \mathrm{~b}$ & $0.00 \mathrm{~b}$ & $0.00 \mathrm{~b}$ & $0.00 \mathrm{~b}$ & $0.00 \mathrm{~b}$ & $0.00 \mathrm{~b}$ & $1.25 \mathrm{a}$ & $6.81 * *$ \\
\hline & $\mathrm{dw}$ & $0.00 \mathrm{~b}$ & $0.00 \mathrm{~b}$ & $0.00 \mathrm{~b}$ & $0.00 \mathrm{~b}$ & $0.00 \mathrm{~b}$ & $0.00 \mathrm{~b}$ & $0.00 \mathrm{~b}$ & $1.77 \mathrm{a}$ & $7.34 * *$ \\
\hline \multirow[t]{2}{*}{ Brachiaria decumbens } & $\mathrm{n}$ & $1.00 \mathrm{~b}$ & $0.00 \mathrm{~b}$ & $0.50 \mathrm{~b}$ & $3.25 \mathrm{a}$ & $1.00 \mathrm{~b}$ & $1.50 \mathrm{~b}$ & $0.25 \mathrm{~b}$ & $3.75 \mathrm{a}$ & $5.35 * *$ \\
\hline & $\mathrm{dw}$ & $0.50 \mathrm{~b}$ & $0.00 \mathrm{~b}$ & $0.14 \mathrm{~b}$ & $2.38 \mathrm{a}$ & $0.54 \mathrm{~b}$ & $0.92 \mathrm{~b}$ & $0.13 \mathrm{~b}$ & $3.20 \mathrm{a}$ & $9.35 * *$ \\
\hline \multirow[t]{2}{*}{ Chamaesyce hirta } & $\mathrm{n}$ & $0.00 \mathrm{a}$ & $0.00 \mathrm{a}$ & $0.00 \mathrm{a}$ & $0.25 \mathrm{a}$ & $0.25 \mathrm{a}$ & $0.00 \mathrm{a}$ & $0.25 \mathrm{a}$ & $0.25 \mathrm{a}$ & $0.57^{\mathrm{ns}}$ \\
\hline & $\mathrm{dw}$ & $0.00 \mathrm{a}$ & $0.00 \mathrm{a}$ & $0.00 \mathrm{a}$ & $0.09 \mathrm{a}$ & $0.29 \mathrm{a}$ & $0.00 \mathrm{a}$ & $0.15 \mathrm{a}$ & $0.30 \mathrm{a}$ & $0.65^{\mathrm{ns}}$ \\
\hline \multirow[t]{2}{*}{ Conyza spp. } & $\mathrm{n}$ & $0.25 \mathrm{~b}$ & $0.00 \mathrm{~b}$ & $0.25 \mathrm{~b}$ & $4.50 \mathrm{a}$ & $0.25 \mathrm{~b}$ & $0.25 \mathrm{~b}$ & $0.25 \mathrm{~b}$ & $4.50 \mathrm{a}$ & $12.76^{* *}$ \\
\hline & $\mathrm{dw}$ & $0.05 \mathrm{c}$ & $0.00 \mathrm{c}$ & $0.04 \mathrm{c}$ & $1.83 \mathrm{~b}$ & $0.34 \mathrm{c}$ & $0.19 \mathrm{c}$ & $0.30 \mathrm{c}$ & $3.96 \mathrm{a}$ & $17.91 * *$ \\
\hline \multirow[t]{2}{*}{ Cyperus rotundus } & $\mathrm{n}$ & $1.75 \mathrm{~b}$ & $1.00 \mathrm{~b}$ & $1.75 \mathrm{~b}$ & $8.00 \mathrm{a}$ & $1.00 \mathrm{~b}$ & $1.25 \mathrm{~b}$ & $1.25 \mathrm{~b}$ & $5.75 \mathrm{a}$ & $2.96 *$ \\
\hline & $\mathrm{dw}$ & $0.55 \mathrm{~b}$ & $0.49 \mathrm{~b}$ & $0.48 \mathrm{~b}$ & $2.28 \mathrm{a}$ & $1.09 \mathrm{~b}$ & $2.01 \mathrm{a}$ & $0.35 \mathrm{~b}$ & $3.55 \mathrm{a}$ & $3.46^{*}$ \\
\hline \multirow[t]{2}{*}{ Digitaria horizontalis } & $\mathrm{n}$ & $0.00 \mathrm{a}$ & $0.00 \mathrm{a}$ & $0.00 \mathrm{a}$ & $0.25 \mathrm{a}$ & $0.00 \mathrm{a}$ & $0.00 \mathrm{a}$ & $0.00 \mathrm{a}$ & $0.25 \mathrm{a}$ & $0.85^{\text {ns }}$ \\
\hline & $\mathrm{dw}$ & $0.00 \mathrm{a}$ & $0.00 \mathrm{a}$ & $0.00 \mathrm{a}$ & $0.33 \mathrm{a}$ & $0.00 \mathrm{a}$ & $0.00 \mathrm{a}$ & $0.00 \mathrm{a}$ & $0.27 \mathrm{a}$ & $0.86^{\mathrm{ns}}$ \\
\hline \multirow[t]{2}{*}{ Galinsoga parviflora } & $\mathrm{n}$ & $0.00 \mathrm{a}$ & $0.00 \mathrm{a}$ & $0.00 \mathrm{a}$ & $0.25 \mathrm{a}$ & $0.00 \mathrm{a}$ & $0.00 \mathrm{a}$ & $0.00 \mathrm{a}$ & $0.75 \mathrm{a}$ & $1.95^{\mathrm{ns}}$ \\
\hline & dw & $0.00 \mathrm{a}$ & $0.00 \mathrm{a}$ & $0.00 \mathrm{a}$ & $0.29 \mathrm{a}$ & $0.00 \mathrm{a}$ & $0.00 \mathrm{a}$ & $0.00 \mathrm{a}$ & $0.79 \mathrm{a}$ & $2.12^{\mathrm{ns}}$ \\
\hline \multirow[t]{2}{*}{ Sida rhombifolia } & $\mathrm{n}$ & $0.00 \mathrm{~b}$ & $0.00 \mathrm{~b}$ & $0.00 \mathrm{~b}$ & $5.25 \mathrm{a}$ & $0.25 \mathrm{~b}$ & $0.00 \mathrm{~b}$ & $0.75 \mathrm{~b}$ & $3.25 \mathrm{a}$ & $15.06 * *$ \\
\hline & dw & $0.00 \mathrm{c}$ & $0.00 \mathrm{c}$ & $0.00 \mathrm{c}$ & $2.75 \mathrm{~b}$ & $0.27 \mathrm{c}$ & $0.00 \mathrm{c}$ & $0.64 \mathrm{c}$ & $4.05 \mathrm{a}$ & $16.36^{* *}$ \\
\hline \multirow[t]{2}{*}{ Total } & $\mathrm{n}$ & $3.25 \mathrm{~b}$ & $2.25 \mathrm{~b}$ & $3.00 \mathrm{~b}$ & $25.5 \mathrm{a}$ & $4.50 \mathrm{~b}$ & $3.75 \mathrm{~b}$ & $4.50 \mathrm{~b}$ & $23.2 \mathrm{a}$ & $32.90 * *$ \\
\hline & $\mathrm{dw}$ & $1.36 \mathrm{~b}$ & $2.28 \mathrm{~b}$ & $0.56 \mathrm{~b}$ & $12.8 \mathrm{a}$ & $4.12 \mathrm{~b}$ & $2.46 \mathrm{~b}$ & $2.66 \mathrm{~b}$ & $22.2 \mathrm{a}$ & $44.70 * *$ \\
\hline
\end{tabular}

rattlepod, provided a good weed control, helping to reduce the use of herbicides in agriculture.

C. rotundus exhibited the highest frequency, density and abundance in the weed community, primarily in treatments without mulching (T4 and T8), followed by Conyza spp., S. rhombifolia, $A$. deflexus and $B$. decumbens. However, the frequency of $A$. deflexus and $B$. decumbens also increased in other treatments, such as in soil with no solarization but with rattlepod (T6) (Figures 1A, 1B and 1C).

The $C$. rotundus species shows a high competitive capacity with common bean, since it exhibits aggressive characteristics, including the release of allelopathic substances, in addition to alternative reproduction mechanisms, a high growth rate and space occupation, making it highly efficient in the use of water, light and nutrients (Tavares et al. 2013, Hussain et al. 2017). This species is also difficult to control, causing reductions in the stand and in a range of commercial crops. For this reason, it is among the 20 weed species that cause the most damage to global agriculture (Panozzo et al. 2009).

The $C$. rotundus infestation declined with the presence of mulch (Figure 1). A similar result was found by Flôres et al. (2017), who observed the efficiency of brachiaria as an inhibitor of weed infestation, in addition to ensuring a better common bean yield. Likewise, Pereira et al. (2011) reported that the presence of black oat and millet decreased the density of $C$. rotundus.

Bidens spp. occurred only in treatment T8, i.e., not solarized and without mulching (Figure 1), indicating that the efficiency of solarization depends on the weed species, as observed by Candido et al. (2011), who found that soil solarization with plastic sheets significantly reduced the weed density and biomass, in both greenhouse and field conditions, but did not completely control Amaranthus spp. This shows that, although solarization is a low-cost method that does not pose a risk or leave residues (Katan et al. 1975), when used in isolation, it is not completely efficient for all the weed species. As such, it should be associated with another type of control technique, such as mulching (Baptista et al. 2006).

Digitaria horizontalis and Galinsoga parviflora exhibited frequency, density and abundance only in treatments $\mathrm{T} 4$ and $\mathrm{T} 8$, in which the soil was not covered with mulch (Figures 1A, 1B and 1C). This 
indicates that the mulches were also efficient against these weeds, even with no solarization effect.

In the second stage of the experiment, the largest number of weeds was found in solarized soil + rattlepod (T2), solarized soil without mulching (T4), non-solarized soil + rattlepod (T6) and non-solarized soil without mulching (T8). The weed dry weight did not differ among the treatments (Table 3).

Frequency was the highest phytosociological index for $A$. deflexus, B. decumbens and C. rotundus.
The highest frequency in treatments with no mulching (T4 and T8) for C. rotundus, regardless of solarization, was observed in treatments of non-solarized soil with rattlepod (T6) and without mulching (T8) (Figure 2A).

Weed density increased in the treatment with non-solarized soil without mulching (T8) and with rattlepod (T6) for B. decumbens and C. rotundus, respectively (Figure 2B). A similar behavior occurred with abundance for these species in treatments $\mathrm{T} 6$
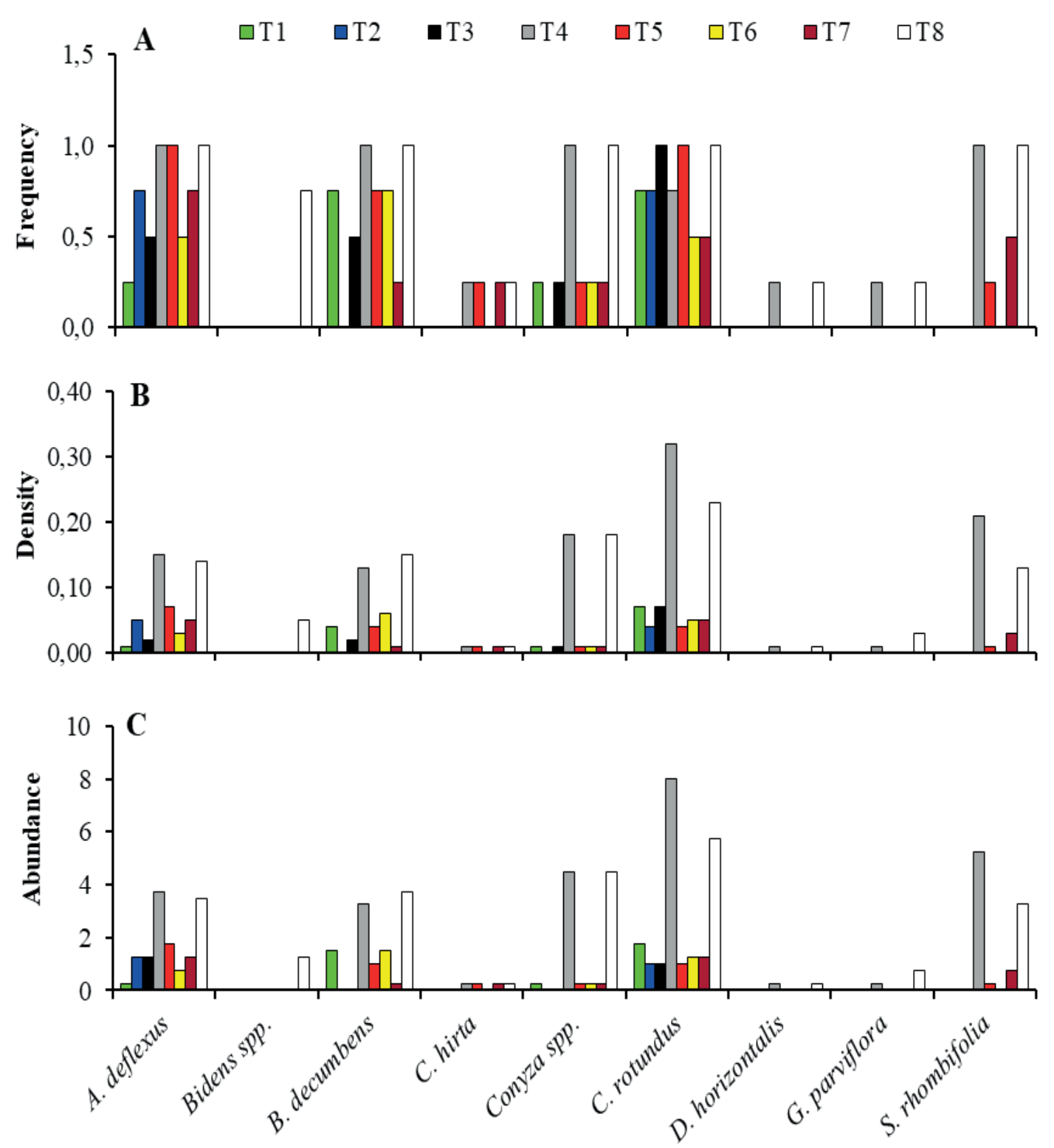

Figure 1. Frequency (A), density (B) and abundance (C) of weeds in the soil with and without solarization, using plastic sheeting associated with mulches in a cowpea crop. T1: solarized soil + castor bean as mulch; T2: solarized soil with rattlepod as mulch; T3: solarized soil with spontaneous vegetation as mulch; T4: solarized soil with no mulch; T5: non-solarized soil + castor bean as mulch; T6: non-solarized soil + rattlepod as mulch; T7: non-solarized soil + spontaneous vegetation as mulch; T8: control - non-solarized and no mulch. 
Table 3. Number $\left(\mathrm{n} ; \mathrm{n} \mathrm{m}^{-2}\right)$ and dry weight $\left(\mathrm{dw} ; \mathrm{g} \mathrm{m}^{-2}\right)$ of weeds in soil with and without solarization with a solar collector, associated with mulches in a cowpea crop.

\begin{tabular}{|c|c|c|c|c|c|c|c|c|c|c|}
\hline \multirow{2}{*}{ Weeds } & \multirow{2}{*}{ Parameters } & \multicolumn{8}{|c|}{ Treatments } & \multirow{2}{*}{ F-value } \\
\hline & & $\mathrm{T} 1$ & $\mathrm{~T} 2$ & T3 & T4 & T5 & T6 & T7 & T8 & \\
\hline \multirow[t]{2}{*}{ Alternanthera tenella } & $\mathrm{n}$ & $0.00 \mathrm{a}$ & $0.50 \mathrm{a}$ & $0.00 \mathrm{a}$ & $0.00 \mathrm{a}$ & $0.00 \mathrm{a}$ & $0.00 \mathrm{a}$ & $0.00 \mathrm{a}$ & $0.00 \mathrm{a}$ & $1.00^{\mathrm{ns}}$ \\
\hline & $\mathrm{dw}$ & $0.00 \mathrm{a}$ & $0.42 \mathrm{a}$ & $0.00 \mathrm{a}$ & $0.00 \mathrm{a}$ & $0.00 \mathrm{a}$ & $0.00 \mathrm{a}$ & $0.00 \mathrm{a}$ & $0.00 \mathrm{a}$ & $1.00^{\mathrm{ns}}$ \\
\hline \multirow[t]{2}{*}{ Amaranthus deflexus } & $\mathrm{n}$ & $0.75 \mathrm{a}$ & $0.50 \mathrm{a}$ & $0.25 \mathrm{a}$ & $0.25 \mathrm{a}$ & $1.75 \mathrm{a}$ & $0.00 \mathrm{a}$ & $0.50 \mathrm{a}$ & $0.75 \mathrm{a}$ & $0.81^{\mathrm{ns}}$ \\
\hline & dw & $1.09 \mathrm{a}$ & $0.68 \mathrm{a}$ & $0.40 \mathrm{a}$ & $0.42 \mathrm{a}$ & $1.49 \mathrm{a}$ & $0.00 \mathrm{a}$ & $1.09 \mathrm{a}$ & $1.28 \mathrm{a}$ & $0.53^{\mathrm{ns}}$ \\
\hline \multirow[t]{2}{*}{ Amaranthus spinosus } & $\mathrm{n}$ & $0.50 \mathrm{a}$ & $0.75 \mathrm{a}$ & $0.00 \mathrm{a}$ & $0.00 \mathrm{a}$ & $0.25 \mathrm{a}$ & $0.00 \mathrm{a}$ & $0.50 \mathrm{a}$ & $0.25 \mathrm{a}$ & $0.74^{\mathrm{ns}}$ \\
\hline & $\mathrm{dw}$ & $0.50 \mathrm{a}$ & $0.95 \mathrm{a}$ & $0.00 \mathrm{a}$ & $0.00 \mathrm{a}$ & $0.21 \mathrm{a}$ & $0.00 \mathrm{a}$ & $1.53 \mathrm{a}$ & $0.18 \mathrm{a}$ & $0.82^{\mathrm{ns}}$ \\
\hline \multirow[t]{2}{*}{ Bidens spp. } & $\mathrm{n}$ & $0.00 \mathrm{a}$ & $0.00 \mathrm{a}$ & $0.25 \mathrm{a}$ & $0.00 \mathrm{a}$ & $0.00 \mathrm{a}$ & $0.00 \mathrm{a}$ & $0.00 \mathrm{a}$ & $0.00 \mathrm{a}$ & $1.00^{\mathrm{ns}}$ \\
\hline & $\mathrm{dw}$ & $0.00 \mathrm{a}$ & $0.00 \mathrm{a}$ & $0.24 \mathrm{a}$ & $0.00 \mathrm{a}$ & $0.00 \mathrm{a}$ & $0.00 \mathrm{a}$ & $0.00 \mathrm{a}$ & $0.00 \mathrm{a}$ & $1.00^{\mathrm{ns}}$ \\
\hline \multirow[t]{2}{*}{ Brachiaria brizantha } & $\mathrm{n}$ & $0.00 \mathrm{a}$ & $0.00 \mathrm{a}$ & $0.00 \mathrm{a}$ & $0.00 \mathrm{a}$ & $0.25 \mathrm{a}$ & $0.00 \mathrm{a}$ & $0.25 \mathrm{a}$ & $0.00 \mathrm{a}$ & $0.85^{\mathrm{ns}}$ \\
\hline & $\mathrm{dw}$ & $0.00 \mathrm{a}$ & $0.00 \mathrm{a}$ & $0.00 \mathrm{a}$ & $0.00 \mathrm{a}$ & $0.26 \mathrm{a}$ & $0.00 \mathrm{a}$ & $0.06 \mathrm{a}$ & $0.00 \mathrm{a}$ & $0.94^{\mathrm{ns}}$ \\
\hline \multirow[t]{2}{*}{ Brachiaria decumbens } & $\mathrm{n}$ & $0.25 \mathrm{~b}$ & $2.25 \mathrm{a}$ & $0.50 \mathrm{~b}$ & $1.75 \mathrm{a}$ & $0.00 \mathrm{~b}$ & $0.00 \mathrm{~b}$ & $1.25 \mathrm{~b}$ & $3.25 \mathrm{a}$ & $4.70 * *$ \\
\hline & $\mathrm{dw}$ & $0.36 \mathrm{~b}$ & $1.24 \mathrm{~b}$ & $0.60 \mathrm{~b}$ & $1.97 \mathrm{a}$ & $0.00 \mathrm{~b}$ & $0.00 \mathrm{~b}$ & $0.56 \mathrm{~b}$ & $3.17 \mathrm{a}$ & $5.17 * *$ \\
\hline \multirow[t]{2}{*}{ Chamaesyce hirta } & $\mathrm{n}$ & $0.25 \mathrm{a}$ & $0.00 \mathrm{a}$ & $0.00 \mathrm{a}$ & $0.00 \mathrm{a}$ & $0.00 \mathrm{a}$ & $0.00 \mathrm{a}$ & $0.00 \mathrm{a}$ & $0.25 \mathrm{a}$ & $0.86^{\mathrm{ns}}$ \\
\hline & $\mathrm{dw}$ & $0.30 \mathrm{a}$ & $0.00 \mathrm{a}$ & $0.00 \mathrm{a}$ & $0.00 \mathrm{a}$ & $0.00 \mathrm{a}$ & $0.00 \mathrm{a}$ & $0.00 \mathrm{a}$ & $0.56 \mathrm{a}$ & $0.88^{\mathrm{ns}}$ \\
\hline \multirow[t]{2}{*}{ Conyza spp. } & $\mathrm{n}$ & $0.00 \mathrm{a}$ & $0.00 \mathrm{a}$ & $0.00 \mathrm{a}$ & $0.00 \mathrm{a}$ & $0.00 \mathrm{a}$ & $0.25 \mathrm{a}$ & $0.25 \mathrm{a}$ & $0.00 \mathrm{a}$ & $0.85^{\mathrm{ns}}$ \\
\hline & dw & $0.00 \mathrm{a}$ & $0.00 \mathrm{a}$ & $0.00 \mathrm{a}$ & $0.00 \mathrm{a}$ & $0.00 \mathrm{a}$ & $0.11 \mathrm{a}$ & $0.13 \mathrm{a}$ & $0.00 \mathrm{a}$ & $0.86^{\mathrm{ns}}$ \\
\hline \multirow[t]{2}{*}{ Cyperus rotundus } & $\mathrm{n}$ & $0.50 \mathrm{~b}$ & $0.00 \mathrm{~b}$ & $0.25 \mathrm{~b}$ & $1.00 \mathrm{~b}$ & $0.00 \mathrm{~b}$ & $4.25 \mathrm{a}$ & $0.00 \mathrm{~b}$ & $0.50 \mathrm{~b}$ & $17.10 * *$ \\
\hline & $\mathrm{dw}$ & $0.11 \mathrm{~b}$ & $0.87 \mathrm{~b}$ & $0.13 \mathrm{~b}$ & $0.58 \mathrm{~b}$ & $0.00 \mathrm{~b}$ & $3.36 \mathrm{a}$ & $0.00 \mathrm{~b}$ & $0.30 \mathrm{~b}$ & $7.17 * *$ \\
\hline \multirow[t]{2}{*}{ Galinsoga parviflora } & $\mathrm{n}$ & $0.00 \mathrm{a}$ & $0.00 \mathrm{a}$ & $0.00 \mathrm{a}$ & $0.50 \mathrm{a}$ & $0.00 \mathrm{a}$ & $0.00 \mathrm{a}$ & $0.00 \mathrm{a}$ & $0.25 \mathrm{a}$ & $0.88^{\mathrm{ns}}$ \\
\hline & dw & $0.00 \mathrm{a}$ & $0.00 \mathrm{a}$ & $0.00 \mathrm{a}$ & $0.49 \mathrm{a}$ & $0.00 \mathrm{a}$ & $0.00 \mathrm{a}$ & $0.00 \mathrm{a}$ & $0.50 \mathrm{a}$ & $0.86^{\mathrm{ns}}$ \\
\hline \multirow[t]{2}{*}{ Leonotis nepetifolia } & $\mathrm{n}$ & $0.00 \mathrm{a}$ & $0.00 \mathrm{a}$ & $0.00 \mathrm{a}$ & $0.75 \mathrm{a}$ & $0.00 \mathrm{a}$ & $0.00 \mathrm{a}$ & $0.00 \mathrm{a}$ & $0.00 \mathrm{a}$ & $1.00^{\mathrm{ns}}$ \\
\hline & dw & $0.00 \mathrm{a}$ & $0.00 \mathrm{a}$ & $0.00 \mathrm{a}$ & $0.59 \mathrm{a}$ & $0.00 \mathrm{a}$ & $0.00 \mathrm{a}$ & $0.00 \mathrm{a}$ & $0.00 \mathrm{a}$ & $0.97^{\mathrm{ns}}$ \\
\hline \multirow[t]{2}{*}{ Sida rhombifolia } & $\mathrm{n}$ & $0.25 \mathrm{a}$ & $0.00 \mathrm{a}$ & $0.00 \mathrm{a}$ & $0.25 \mathrm{a}$ & $0.00 \mathrm{a}$ & $0.00 \mathrm{a}$ & $0.00 \mathrm{a}$ & $0.00 \mathrm{a}$ & $0.85^{\text {ns }}$ \\
\hline & $\mathrm{dw}$ & $0.28 \mathrm{a}$ & $0.00 \mathrm{a}$ & $0.00 \mathrm{a}$ & $0.15 \mathrm{a}$ & $0.00 \mathrm{a}$ & $0.00 \mathrm{a}$ & $0.00 \mathrm{a}$ & $0.00 \mathrm{a}$ & $0.87^{\mathrm{ns}}$ \\
\hline \multirow[t]{2}{*}{ Tridax procumbens } & $\mathrm{n}$ & $0.50 \mathrm{a}$ & $0.00 \mathrm{a}$ & $0.00 \mathrm{a}$ & $0.25 \mathrm{a}$ & $0.00 \mathrm{a}$ & $0.00 \mathrm{a}$ & $0.00 \mathrm{a}$ & $0.25 \mathrm{a}$ & $1.37^{\mathrm{ns}}$ \\
\hline & $\mathrm{dw}$ & $0.55 \mathrm{a}$ & $0.00 \mathrm{a}$ & $0.00 \mathrm{a}$ & $0.21 \mathrm{a}$ & $0.00 \mathrm{a}$ & $0.00 \mathrm{a}$ & $0.00 \mathrm{a}$ & $0.20 \mathrm{a}$ & $2.08^{\mathrm{ns}}$ \\
\hline \multirow[t]{2}{*}{ Total } & $\mathrm{n}$ & $3.00 \mathrm{~b}$ & $4.00 \mathrm{a}$ & $1.25 \mathrm{~b}$ & $4.75 \mathrm{a}$ & $2.25 \mathrm{~b}$ & $4.50 \mathrm{a}$ & $3.00 \mathrm{~b}$ & $5.25 \mathrm{a}$ & $2.47 *$ \\
\hline & $\mathrm{dw}$ & $3.23 \mathrm{a}$ & $4.18 \mathrm{a}$ & $1.38 \mathrm{a}$ & $4.36 \mathrm{a}$ & $1.96 \mathrm{a}$ & $3.48 \mathrm{a}$ & $3.57 \mathrm{a}$ & $6.01 \mathrm{a}$ & $1.73^{\mathrm{ns}}$ \\
\hline
\end{tabular}

and T8, while, for $A$. deflexus, the greatest abundance was in T5, with non-solarized soil and castor bean (Figure 2C).

Thus, in addition to soil treatments without mulching, rattlepod depends on solarization to inhibit the infestation by weeds such as $C$. rotundus. According to Monquero et al. (2009), a small amount of rattlepod on the soil surface does not inhibit the weed infestation, while larger amounts resulted in the emergence of weakened weeds, with yellowing, necrosis and deformed leaves, likely due to physical and/or chemical effects. The small amount of rattlepod used in the present study likely resulted in the inefficient control of weed infestation, especially C. rotundus, since it propagates aggressively (Panozzo et al. 2009, Hussain et al. 2017). Thus, a large amount of rattlepod exhibits an allelopathic effect, which is the inhibitory or stimulating effect of a plant on other species, resulting from the release of chemical substances into the environment and contributing to reduce the weed population (Scholberg et al. 2006).

On the other hand, the fact that $A$. deflexus had a greater density and abundance in non-solarized soil with castor bean reinforces the efficiency of solarization associated with mulching. These results confirm that solarization is a good control technique to reduce the number of weeds in farm crops (Ricci et al. 2000, Candido et al. 2011, Samtani et al. 2017), although it does not inhibit all weeds.

In this study, the use of castor bean as mulch in non-solarized soil was not completely efficient in controlling weeds, a finding also reported by Meschede et al. (2007), who observed that castor bean allowed a greater soil exposure and higher 

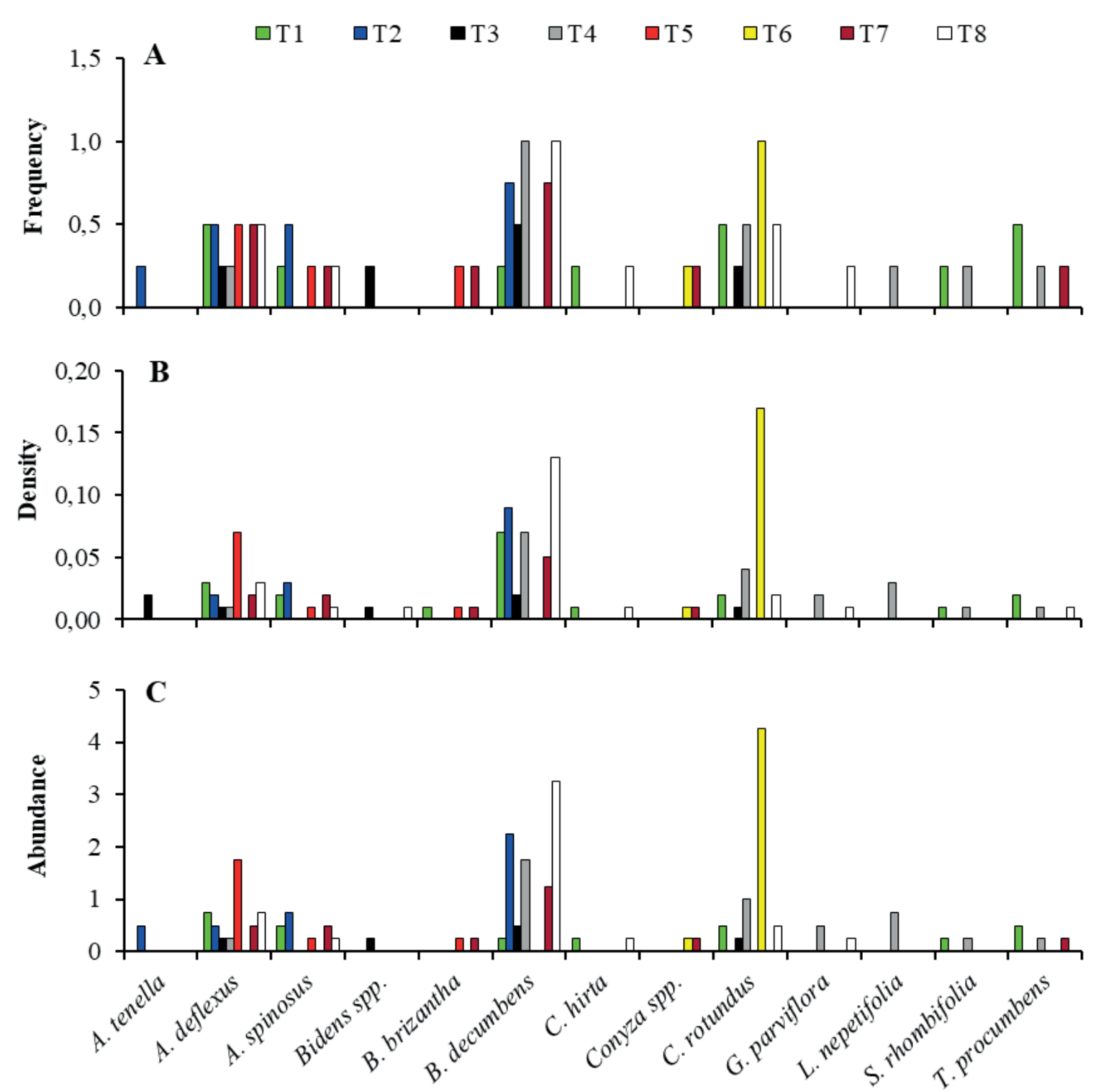

Figure 2. Frequency (A), density (B) and abundance (C) of weeds in soil solarized and not solarized with a solar collector, associated with mulches in a cowpea crop. T1: solarized soil + castor bean as mulch; T2: solarized soil with rattlepod as mulch; T3: solarized soil with spontaneous vegetation as mulch; T4: solarized soil with no mulch; T5: non-solarized soil + castor bean as mulch; T6: non-solarized soil + rattlepod as mulch; T7: non-solarized soil + spontaneous vegetation as mulch; T8: control - non-solarized and no mulch.

weed incidence and density. With these results, it is suggested that castor bean alone is not efficient in the weed control, but is a good strategy, when associated with solarization.

\section{CONCLUSIONS}

1. Cyperus rotundus, Brachiaria decumbens and Amaranthus deflexus exhibit a high frequency in cowpea crops in solarized and non-solarized soil with no mulching;
2. Solarization with a solar collector is more efficient than with plastic sheeting in the weed control, but efficiency depends on the weed species;

3. Mulching inhibits the weed infestation in cowpea crops, irrespective of soil solarization. However, depending on the type of solarization, rattlepod is more efficient in soil solarized with plastic sheeting than with a solar collector;

4. Mulching with castor bean inhibits the number of weeds, irrespective of soil solarization; however, does not interfere with the accumulation of dry mass. 


\section{REFERENCES}

BAPTISTA, M. J. et al. Solarização do solo e biofumigação no cultivo protegido de tomate. Horticultura Brasileira, v. 24, n. 1, p. 47-52, 2006.

BRAUN-BLANQUET, J. Fitossociologia: bases para el estudio de las comunidades vegetales. Madrid: H. Blume, 1979.

CABRAL, P. H. R. et al. Interferência de plantas daninhas na cultura do sorgo cultivado em safrinha. Pesquisa Agropecuária Tropical, v. 43, n. 3, p. 308-314, 2013.

CANDIDO, V. et al. Weed control and yield response of soil solarization with different plastic films in lettuce. Scientia Horticulturae, v. 130, n. 3, p. 491-497, 2011.

CARDOSO, A. D. et al. Levantamento fitossociológico de plantas daninhas na cultura da mandioca em Vitória da Conquista, Bahia. Bioscience Journal, v. 29, n. 5, p. 1130-1140, 2013.

FLÔRES, J. A. et al. Agronomic and qualitative traits of common bean as a function of the straw and nitrogen fertilization. Pesquisa Agropecuária Tropical, v. 47, n. 2, p. 195-201, 2017.

FREITAS, F. C. L. et al. Interferência de plantas daninhas na cultura do feijão-caupi. Planta Daninha, v. 27, n. 2, p. 241-247, 2009.

GATTI, A. B. et al. Allelopathic effects of aqueous extracts of Aristolochia esperanzae O. Kuntze on development of Sesamum indicum L. seedlings. Acta Botanica Brasilica, v. 24, n. 2, p. 454-461, 2010.

HUSSAIN, I. et al. Allelopathic potential of sesame plant leachate against Cyperus rotundus L. Annals of Agrarian Science, v. 15, n. 1, p. 141-147, 2017.

KATAN, J. R. et al. Solar heating polyethylene mulching for the control of diseases caused by soil-borne pathogens. Phytopathology, v. 66, n. 5, p. 683-688, 1975.

KUVA, M. A. et al. Períodos de interferências das plantas daninhas na cultura da cana-de-açúcar: III. Capim braquiária (Brachiaria decumbens) e capim-colonião (Panicum maximum). Planta Daninha, v. 21, n. 1, p. 3744, 2003.

LIMA, R. S. et al. Levantamento fitossociológico de plantas daninhas na cultura do feijão-caupi no município de Vitória da Conquista - BA. Magistra, v. 28, n. 3/4, p. 390-402, 2016.

MESCHEDE, D. K. et al. Avaliação de diferentes coberturas na supressão de plantas daninhas no Cerrado. Planta Daninha, v. 25, n. 3, p. 465-471, 2007.
MONQUERO, P. A. et al. Efeito de adubos verdes na supressão de espécies de plantas daninhas. Planta Daninha, v. 27, n. 1, p. 85-95, 2009.

PANOZZO, L. E. et al. Métodos de manejo de Cyperus esculentus na lavoura de arroz irrigado. Planta Daninha, v. 27, n. 1, p. 165-174, 2009.

PEREIRA, R. A. et al. Influência da cobertura de aveiapreta e milheto sobre comunidade de plantas daninhas e produção de soja. Revista Brasileira de Ciências Agrárias, v. 6, n. 1, p. 1-10, 2011.

RICCI, M. S. F. et al. Efeitos da solarização do solo na densidade populacional da tiririca e na produtividade de hortaliças sob manejo orgânico. Pesquisa Agropecuária Brasileira, v. 35, n. 11, p. 2175-2179, 2000.

RODRIGUES, M. H. B. S. et al. Fitossociologia de plantas espontâneas sob cultivo agroecológico na bananeira no sertão paraibano. Revista Verde de Agroecologia e Desenvolvimento Sustentável, v. 12, n. 1, p. 12-16, 2017.

SALGADO, T. P. et al. Interferência das plantas daninhas no feijoeiro carioca. Planta Daninha, v. 25, n. 3, p. 443448, 2007.

SAMTANI, J. B. et al. Evaluating soil solarization for weed control and strawberry (Fragaria xananassa) yield in annual plasticulture production. Weed Technology, v. 31, n. 3, p. 455-463, 2017.

SCHOLBERG, J. M. S. et al. Integrative approaches for weed management in organic citrus orchards. HortScience, v. 41, n. 4, p. 949-954, 2006.

SILVA, H. A. P. et al. Expressão gênica induzida por estresses abióticos em nódulos de feijão-caupi. Pesquisa Agropecuária Brasileira, v. 47, n. 6, p. 797-807, 2012.

SOARES, M. B. B. et al. Fitossociologia de plantas daninhas sob diferentes sistemas de manejo de solo em áreas de reforma de cana crua. RevistaAgro@mbiente On-Line, v. 5, n. 3, p. 173-181, 2011.

STAPLETON, J. J.; DeVAY, J. E. Soil solarization: a natural mechanism of integrated pest management. In: REUVENI, R. (Ed.). Novel approaches to integrated pest management. Boca Raton: CRC Press, 1995. p. 309-350.

TAVARES, C. J. et al. Fitossociologia de plantas daninhas na cultura do feijão. Revista Brasileira de Ciências Agrárias, v. 8, n. 1, p. 27-32, 2013.

VINCENSI, M. M. et al. Manejo do solo e adubação nitrogenada na supressão de plantas daninhas na cultura do feijão de inverno e irrigado. Revista Ciência Agronômica, v. 42 , n. 3, p. 758-764, 2011. 